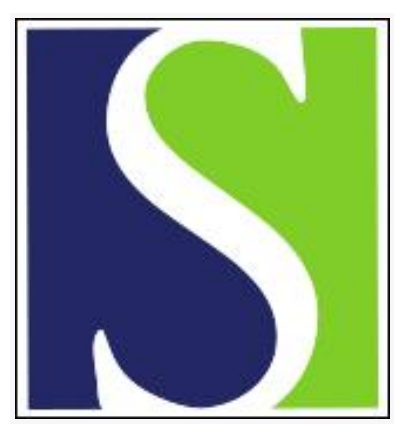

Scand J Work Environ Health 1984;10(4):263-266

https://doi.org/10.5271/sjweh.2332

Issue date: Aug 1984

Solvent exposure in construction and maintenance painting.

by Riala R, Kalliokoski P, Pyy L, Wickstrom G

This article in PubMed: www.ncbi.nlm.nih.gov/pubmed/6494847

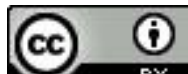




\title{
Solvent exposure in construction and maintenance painting
}

\author{
by Riitta Riala, MSc (Eng), ${ }^{1}$ Pentti Kalliokoski, PhD, ${ }^{2}$ Lauri Pyy, MSc, ${ }^{3}$ Gustav Wickström, MD ${ }^{4}$
}

\begin{abstract}
RIALA R, KALLIOKOSKI P, PYY L, WICKSTRÖM G. Solvent exposure in construction and maintenance painting. Scand $J$ Work Environ Health 10 (1984) 263-266. Exposure to solvents in interior house painting was determined by industrial hygiene surveys and questionnaires on work history. Painting work was observed in 92 work situations at 18 sites, mainly during maintenance work. The effects of the size of the work area, the volume of air, the type of paint, the amount used, the method of application, and the use of ventilation on the solvent concentrations were also studied. In small, poorly ventilated rooms the concentration of solvent naphtha averaged $275 \mathrm{ppm}$ when alkyd paints were used. Wall and ceiling painting with alkyd paints yielded an average solvent naphtha concentration of $210 \mathrm{ppm}$, and window and door painting $80 \mathrm{ppm}$. The presence of a strong draft reduced the solvent concentrations by twothirds. The painters' average lifetime dose of solvent naphtha was $12.2 \mathrm{~kg}$, the average annual dose $0.54 \mathrm{~kg}$. These levels decreased over the study period. The mean $8-\mathrm{h}$ concentration of solvent naphtha in the breathing zone averaged 40 ppm over the painters' total worklife.
\end{abstract}

Key terms: alkyd paint, house painting, retrospective industrial hygiene survey, solvent naphtha.

In the Finnish construction industry during the 1970s there was a considerable decrease in the use of paints containing organic solvents. Today only about $40 \%$ of the 20,000 t of paint used annually in construction work contains organic solvents, the other $60 \%$ is some type of water-based latex paint.

Paints containing solvents are used in new buildings only for special purposes, eg, for radiators, window frames, and floors in damp areas. In addition, more and more building elements (kitchen fittings, for instance) are prefabricated in factories with good work conditions and are merely installed on site. However wood preservatives that contain solvents have become popular, mainly for wood intended for outdoor use.

Solvent-based paints, especially the alkyd type, are still in widespread use during maintenance work. In addition to being used for window frames, doors, and kitchen cabinets, they are also put on walls and ceilings. Painters are thus more commonly exposed to solvents during maintenance work than during painting at new building sites.

About 9,000 Finns work as professional construction and maintenance painters. They usually start out at new building sites, but as they gain experience they prefer maintenance work, which requires better quality and is more time-consuming. As the use of

1 Uusimaa Regional Institute of Occupational Health, SF-00370 Helsinki, Finland.

2 University of Kuopio, SF-70101 Kuopio, Finland.

3 Oulu Regional Institute of Occupational Health, SF-90101 Oulu, Finland.

4 Turku Regional Institute of Occupational Health, SF-20500 Turku, Finland.

Reprint requests to: Ms R Riala, Uusimaa Regional Institute of Occupational Health, Arinatie $3 \mathrm{~A}, \mathrm{SF}-00370 \mathrm{Hel}-$ sinki, Finland. solvent-based paints was common also in new buildings some 10 to 30 years ago, older painters have therefore been exposed to solvents practically all their worklife.

An extensive Swedish study on painters' work performed under laboratory conditions showed that some work methods resulted in exposure to high levels of solvents (2). In another Swedish study on spray painting, it was indicated that solvent exposure reached concentrations equivalent to $1,500 \mathrm{ppm}$ of solvent naphtha (1).

The present investigation was carried out to determine the current level of exposure to solvents during the interior painting of buildings. The solvent concentrations were measured for various work phases. In addition a retrospective industrial hygiene survey combined the measured solvent concentrations with the results of a questionnaire study on previous work conditions.

\section{Materials and methods}

Current exposure. The painters' present exposure to solvents was determined from industrial hygiene surveys of 16 maintenance sites and 2 new building sites. Altogether 92 work phases were studied. The sites included three office buildings, five schools, four apartments (or flats), five public buildings, and one factory. Ceilings, floors, walls, kitchen cabinets, window frames, doors, and the walls of staircases were painted during the study.

Alkyd paint or alkyd lacquer (which contain 30$50 \%$ solvent naphtha as the primary solvent) was used at 15 sites. [Solvent naphtha (White Spirit, Stoddard solvent) has the boiling range $140-200^{\circ} \mathrm{C}$ and contains $17 \%$ aromatic hydrocarbons (xylene, tri- 
methyl benzene, ethyl benzene).] Epoxy paints (which contain toluene, xylene, aliphatic alcohols, and ketones as solvents) were being used at the two new building sites: A wood preservative diluted with solvent naphtha was used at one site, and urethane lacquer (which also contains solvent naphtha) was used at another site. Spray painting was done in three buildings.

The concentration of solvents in the air depends mainly on the amount of paint used and the volume of dilution air. The former is directly related to the area to be painted, the latter to the volume of the room and its rate of ventilation. Thus the amount of paint used, the type of ventilation, and the dimensions of the workroom and the area painted were always recorded. The results of the various work phases were categorized according to these factors.

Solvent vapor samples were taken by the routine personal sampling method with small portable pumps (Sipin SP-1) and charcoal tubes. The duration of the sampling varied from $15 \mathrm{~min}$ to about $3 \mathrm{~h}$, depending on the work. The sampling rate was 200 $\mathrm{ml} / \mathrm{min}$. Solvents were desorbed from the charcoal by dimethyl formamide and analyzed with a gas chromatograph equipped with a stainless steel column (length $1.5 \mathrm{~m}$, inner diameter $2.2 \mathrm{~mm}$ ) packed with $10 \%$ Carbowax $20 \mathrm{M}$ and $3 \%$ sodium hydroxide on Chromosorb P (80-100 mesh). The column temperature was $80^{\circ} \mathrm{C}$, and the flow rate of the carrier gas nitrogen was $30 \mathrm{ml} / \mathrm{min}$. The results presented in table 1 were obtained with these procedures.

Previous exposure. The questionnaire on work history covered 231 painters, who had also participated in a thorough psychological and neurophysiological examination $(4,6)$. The painters answered questions on the length of painting work, the paints they had used throughout their worklife, the amount of actual painting work and that of prelinninary work and wallpapering, their work conditions, and the frequency of "drunkenness" caused by the solvents in paints.

Each individual painter's average exposure to solvents was calculated from the questionnaire data on both the amount of time spent working in different types of rooms and the proportions of different types of paints. The doses of exposure to solvents for three different periods of time (total worklife, the past five years, and the last year) were calculated on the basis of the workhours spent on actual indoor painting work and the average concentrations of solvents measured during various work phases (5).

Because solvent naphtha is by far the most common organic solvent contained in paints, the concentrations of the other solvents were converted to corresponding solvent naphtha concentrations to facilitate the calculation of individual doses of exposure to solvents. The Swedish hygienic limits from 1978 were used in the conversion. Thus, for example, the Swedish hygienic limit for xylene or toluene $(80 \mathrm{ppm})$ or the hygienic limit for ethanol $(1,000 \mathrm{ppm})$ corresponded to the hygienic limit for solvent naphtha ( 85 ppm). This conversion method gives a rough estimation of the mixed exposure to various paint solvents, but it also simplifies the picture given of the toxicologic effects of the solvents.

\section{Results}

Current exposure. A summary of the solvent naphtha concentrations to which the painters were exposed

Table 1. Airborne concentrations of solvent naphtha in alkyd and urethane painting and varnishing.

\begin{tabular}{|c|c|c|c|c|c|c|}
\hline \multirow{3}{*}{ Type of room ${ }^{a}$} & \multicolumn{6}{|c|}{ Average concentration of solvent naphtha } \\
\hline & \multicolumn{2}{|c|}{ Ventilation ${ }^{b}$} & \multicolumn{2}{|c|}{ No ventilationc } & \multicolumn{2}{|c|}{ Total } \\
\hline & $\begin{array}{l}\text { Number of } \\
\text { samples }\end{array}$ & $\begin{array}{c}\text { Concentration } \\
(\mathrm{ppm})\end{array}$ & $\begin{array}{l}\text { Number of } \\
\text { samples }\end{array}$ & $\begin{array}{c}\text { Concentration } \\
\text { (ppm) }\end{array}$ & $\begin{array}{l}\text { Number of } \\
\text { samples }\end{array}$ & $\begin{array}{l}\text { Concentration } \\
\text { (ppm) }\end{array}$ \\
\hline Roller and brush painting & 26 & 38 & 43 & 194 & 69 & 135 \\
\hline Cellars and small rooms & 10 & 42 & 15 & 275 & 25 & 181 \\
\hline $\begin{array}{l}\text { Door and window frames } \\
\text { Walls, floors and cabinets }\end{array}$ & $\begin{array}{l}5 \\
5\end{array}$ & $\begin{array}{l}37 \\
46\end{array}$ & $\begin{array}{r}4 \\
11\end{array}$ & $\begin{array}{l}198 \\
303\end{array}$ & $\begin{array}{r}9 \\
16\end{array}$ & $\begin{array}{l}109 \\
223\end{array}$ \\
\hline Medium-sized rooms & 4 & 72 & 16 & 128 & 20 & 116 \\
\hline $\begin{array}{l}\text { Doors and window frames } \\
\text { Walls and ceilings }\end{array}$ & $\begin{array}{l}2 \\
2\end{array}$ & $\begin{array}{l}85 \\
58\end{array}$ & $\begin{array}{r}3 \\
13\end{array}$ & $\begin{array}{l}104 \\
133\end{array}$ & $\begin{array}{r}5 \\
15\end{array}$ & $\begin{array}{r}96 \\
123\end{array}$ \\
\hline Large rooms & 12 & 24 & 12 & 180 & 24 & 102 \\
\hline $\begin{array}{l}\text { Doors and window frames } \\
\text { Walls, floors and ceilings }\end{array}$ & $\begin{array}{l}4 \\
8\end{array}$ & $\begin{array}{l}14 \\
29\end{array}$ & $\begin{array}{r}2 \\
10\end{array}$ & $\begin{array}{r}49 \\
206\end{array}$ & $\begin{array}{r}6 \\
18\end{array}$ & $\begin{array}{r}26 \\
127\end{array}$ \\
\hline Spray painting & 5 & 39 & 3 & 235 & 8 & 115 \\
\hline $\begin{array}{l}\text { Medium-sized rooms, ceilings } \\
\text { Large rooms, ceilings }\end{array}$ & $\begin{array}{l}1 \\
4\end{array}$ & $\begin{array}{r}113 \\
20\end{array}$ & $\begin{array}{l}1 \\
2\end{array}$ & $\begin{array}{l}220 \\
243\end{array}$ & $\begin{array}{l}2 \\
6\end{array}$ & $\begin{array}{r}176 \\
94\end{array}$ \\
\hline Total & 31 & 38 (SD 36) & 46 & 197 (SD 142) & 77 & 132 (SD 134) \\
\hline
\end{tabular}


during painting and varnishing work is presented in table 1. The average concentrations were calculated as the mean concentrations of the single sampling periods. The equivalent solvent naphtha concentrations varied widely according to the work conditions. As expected, the highest concentrations were measured when large surfaces were painted in small, poorly ventilated rooms. Under such circumstances, the average solvent naphtha concentration was about $300 \mathrm{ppm}$. These conditions were typical when lavatories or showerroom walls were painted.

Because a large amount of paint was used, the solvent naphtha concentration was always high when walls or ceilings were painted with solvent-based paints, the average value being $210 \mathrm{ppm}$ for 21 samples (including samples from all sizes of work areas).

Door and window-frame painting represented the painting of small surfaces $(\mathrm{N}=20)$. If no other painting was carried out simultaneously, the average solvent naphtha concentration was $35 \mathrm{ppm}(\mathrm{N}=14)$. However, in a small apartment where one painter worked on kitchen cabinets while another painted doors, the latter was exposed to an average solvent naphtha concentration of $210 \mathrm{ppm}(\mathrm{N}=4)$. In this case the cold outdoor temperature prevented ventilation through the windows.

Ventilation had a crucial impact on the concentration of solvent vapor. When it was possible to create a strong draft through the room by opening the doors and windows, the painters' exposure was diminished to about one-fifth of the levels measured when the windows were closed. The average solvent naphtha concentration during roller and brush painting was $38 \mathrm{ppm}$ with good natural or mechanical ventilation and $194 \mathrm{ppm}$ with no ventilation.

Spray painting is an uncommon method at construction and maintenance sites in Finland. In the two buildings where alkyd paint was sprayed, the average solvent naphtha concentration was $115 \mathrm{ppm}$ $(\mathrm{N}=8)$. Here, again, ventilation affected the concentrations of the solvent. Rooms with mechanical ventilation had a solvent concentration of less than one-fifth of the concentrations measured in rooms with no ventilation. However, spray painters were not exposed to high solvent concentrations because they used respirators.

The exposure to solvent-based paints other than the alkyd type was determined in only a few work situations. The average solvent naphtha concentration was $67 \mathrm{ppm}$ when doors were being finished with a wood preservative $(\mathrm{N}=6)$.

When epoxy paint was sprayed on the ventilation ducts of a new factory $(\mathrm{N}=7)$, the average additive effect of the solvent vapor concentration was $66 \%$ (calculated from the threshold limit values of the American Conference of Governmental Industrial Hygienists (ACGIH) for 1981 and the ACGIH formula for the additive effect of components with similar toxicologic effects). This site was ventilated mechanically, and respirators were used. When the roller method was used with epoxy paint to paint cellar floors, the additive effect was $37 \%$. The low concentration was mainly due to the short duration of the work $(4 \mathrm{~min})$.

Previous exposure. All 231 painters who participated in the questionnaire study responded to the first questionnaire which dealt with their previous and present work conditions. A supplementary questionnaire was later completed by 195 painters.

The painters had entered their occupation when young, $63 \%$ at the age of 19 or younger. Their mean age was 42 (SD 9.1) years at the time of the investigation. They had worked as painters an average of 22 (SD 8.5) years, and had done maintenance painting for an average of 11 years. Eighty-seven percent had worked mainly indoors. About $60 \%$ estimated that they actually painted at least one-half of their work time. The other $40 \%$ used more time plastering, wallpapering, and doing preliminary work.

The questionnaire study confirmed that the use of water-based paints has definitely increased, even in maintenance painting, during the 1970s (figure 1). At present two-thirds of the painters use only latex paint most of their work time. The paints (eg, epoxy and vinyl paints) with the most hazardous solvents were used extensively by only $5 \%$ of the painters interviewed.

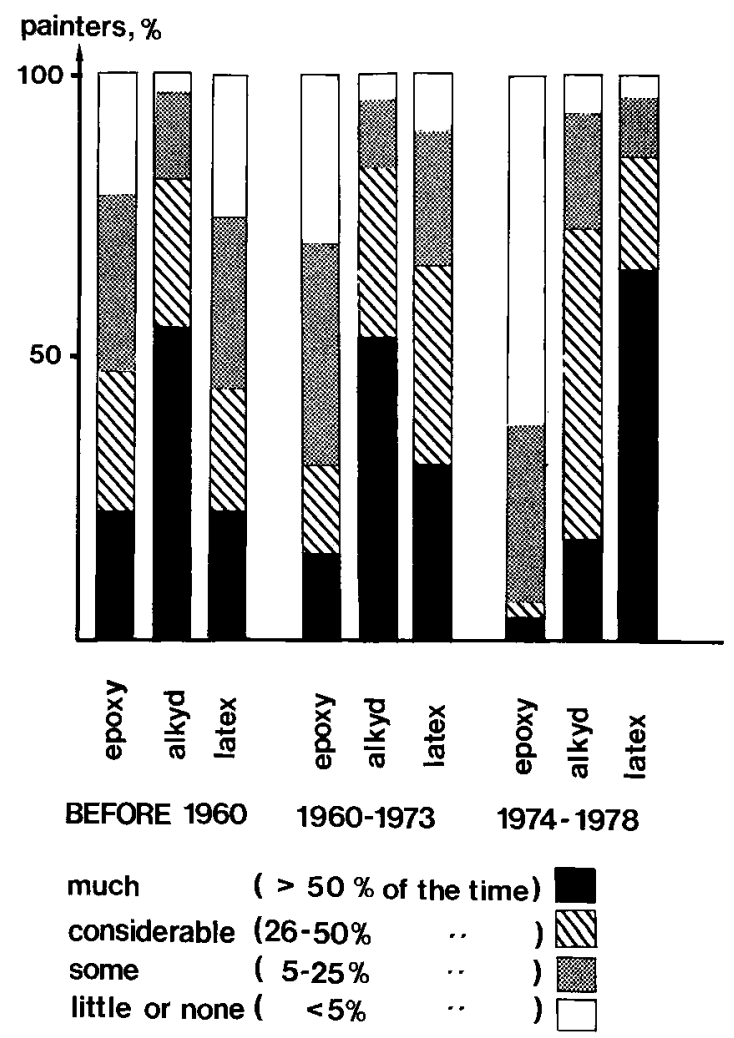

Figure 1. Change in the use of various types of paint. 
About half of the workers who generally used paints containing solvents declared that they nearly always wore respirators during such work. As was stated earlier, spray painting is very rare in maintenance work in Finland, and more than $90 \%$ of the workers reported that they spray painted very seldom.

Drunkenness caused by solvent vapors from paints showed high personal and time-dependent variation. Between 1960 and 1973, when the use of solventbased paints was at its height, the feeling of drunkenness was estimated to have occurred often, on an average of 46 times a year. Between 1974 and 1978 the occurrence of drunkenness averaged only 27 times a year.

Between 1960 and 1973 drunkenness was experienced very often (100 or more times per year) by $8 \%$ of the workers. The painters reported that solventbased epoxy paints were the main cause.

The average exposure dose for all the painters throughout all their years of painting was 11.9 (SD $8.5) \mathrm{kg}$ of solvent naphtha. The average yearly dose was $0.53 \mathrm{~kg}$. In 1977 the mean dose of exposure was only $0.32 \mathrm{~kg}$, a finding indicative of the improved work conditions. The mean 8 -h concentration of solvent naphtha in the maintenance painter's breathing zone averaged $40 \mathrm{ppm}$ for their total work time. For 1977 the corresponding value was only $25 \mathrm{ppm}$.

\section{Discussion}

The maintenance painters' average daily exposure to solvent naphtha was suprisingly low $(40 \mathrm{ppm})$ when the concentration levels of various work situations are considered. When solvent-based alkyd paints were used, the airborne concentrations of solvent naphtha usually exceeded $100 \mathrm{ppm}$, often even 200 ppm during the work phase. This apparent discrepancy was partly caused by the extensive use of water-based paints in the construction and maintenance industry and partly by the relatively small proportion of time spent actually painting.

Water-based latex paints replaced other types of paint during the 1970s. At the same time, the paints containing volatile aromatic hydrocarbons (eg, epoxy paints) practically disappeared from construction and maintenance sites. Today the most commonly used solvent-based paint is that of the alkyd type, with a solvent naphtha concentration of $30-40$ weight \%. It is often used during maintenance work in homes.

The results showing a fairly low average exposure to solvents among maintenance house painters are supported by the findings of the neurophysiological and psychological examinations made in conjunction with the present study. The neurophysiological examinations indicated no significant changes (6). Even though poor performance was found on some of the psychological tests (4) and acute symptoms (drunkenness during work, nausea, irritation of mucous membranes) were more frequent among the painters than the referents, the results of the psychological investigation indicated milder changes than in previous Finnish studies on occupational exposure to solvents [eg, the car painter study (3)]. Since these studies concerned only active painters, they do not however provide information on the health effects of solvents on those who have left this occupation.

Construction and maintenance painters are no longer heavily exposed to solvents even though they occasionally perform tasks in which the solvent concentration, especially that of solvent naphtha, is considerable. Under such circumstances preventive measures are still vital. Good ventilation would be ideal for this purpose. However, it is often difficult to achieve in construction work, and the use of respirators is also important.

\section{References}

1. Bobjer O, Knave B. Work load and exposure to solvents and dust-hazard factors in house painting. In: International symposium of the control of air pollution in the working environment, Stockholm (Sweden) 6-8 September 1977: Part II Solvents, welding. The Work Environment Fund, Stockholm 1977, pp 37-61.

2. Hallin N. Arbetshygieniska problem vid måleriarbete. [Industrial hygiene problems in painting]. Bygghälsan, Stockholm 1975.

3. Husman K. Symptoms of car painters with long-term exposure to a mixture of organic solvents. Scand J Work Environ Health 6 (1980) 19-32.

4. Lindström K, Wickström G. Psychological function changes among maintenance house painters exposed to low levels of organic solvent mixtures. Acta Psychiatr Scand Suppl 303 (1983) 81-91.

5. Riala R, Kalliokoski P. Raudoittaja- ja maalaritutkimus: Osa 5 Altistuminen liuotinaineille korjausmaalaustyössä [Solvent exposure in maintenance house painting]. Institute of Occupational Health, Helsinki 1980. (Työterveyslaitoksen tutkimuksia 171).

6. Seppäläinen AM. Neurophysiological findings among workers exposed to organic solvents. Scand J Work Enrivon Health 7 (1981): suppl 4, 29-33.

Received for publication: 19 March 1984 